\title{
RANCANG BANGUN GRAPHICAL USER INTERFACE SEBAGAI SISTEM MONITORING NIRKABEL PENDETEKSI HUJAN, SUHU DAN KELEMBABAN
}

\author{
Yudhi Ardiyanto ${ }^{1}$, Muhamad Yusvin Mustar ${ }^{2}$ \\ ${ }^{1,2}$ Program Studi Teknik Elektro, Fakultas Teknik, Universitas Muhammadiyah Yogyakarta \\ email : yudhi.ardiyanto@umy.ac.id
}

\begin{abstract}
This paper proposes a wireless monitoring system that is integrated into one to detect rain, temperature, and humidity with electricity sources derived from solar-based solar power plants based on solar power systems, besides the results of monitoring are designed based on GUI (graphical user interface) using Processing, so it can be monitored via a computer (PC or Laptop) remotely. The sensor used for monitoring consists of a rain sensor (Raindrop Sensor), a temperature sensor (NTC Thermistor) and a humidity sensor (HIH-4030). The results of the three sensor readings are input on the microcontroller (Arduino Mega 2560) as a data processing process which will then be transmitted via radio telemetry wirelessly to the user. The results of this study can provide a wireless monitoring system model for rain, temperature and humidity detection integrated into one, so that it can facilitate officers who want to monitor at a particular location or region, without having to be located during monitoring rain, temperature, and humidity detection.
\end{abstract}

Keywords: graphical user interface, HIH-4030, NTC thermistor, processing, raindrop sensor

\begin{abstract}
ABSTRAK
Paper ini mengusulkan sebuah sistem monitoring nirkabel yang terintegrasi menjadi satu dalam melakukan pendeteksian hujan, suhu dan kelembaban dengan catu daya yang berasal dari solar DC power system, selain itu hasil monitoring didesain berbasis GUI (graphical user interface) menggunakan Processing, sehingga dapat di monitor melalui komputer (PC atau Laptop) dari jarak jauh. Sensor yang digunakan untuk melakukan monitoring terdiri dari sensor hujan (Raindrop Sensor), sensor suhu (NTC Thermistor) dan sensor kelembaban (HIH-4030). Hasil pembacaan ketiga sensor tersebut di inputkan pada mikrokontroller (Arduino Mega 2560) sebagai proses pengolahan data yang selanjutnya akan ditransmisikan melalui radio telemetry secara nirkabel kepada user. Hasil penelitian ini mampu memberikan sebuah model sistem monitoring nirkabel deteksi hujan, suhu dan kelembaban yang terintegrasi menjadi satu, sehingga dapat memudahkan petugas yang ingin melakukan monitoring pada lokasi atau wilayah tertentu, tanpa harus berada dilokasi selama melakukan monitoring pendeteksian hujan, suhu dan kelembaban.
\end{abstract}

Kata kunci: graphical user interface, HIH-4030, NTC thermistor, processing, sensor raindrop

\section{PENDAHULUAN}

Sistem monitoring digunakan untuk mengetahui atau mendapatkan sebuah informasi keadaan atau kondisi di sebuah tempat atau daerah tertentu, dengan berbagai metode yang digunakan, sehingga sistem monitoring banyak dikembangkan dan diaplikasikan untuk membantu tugas manusia dalam melakukan pemantauan. Sistem pemantauan yang diaplikasikan dalam smart home untuk membantu kegiatan orang jompo di rumah tersebut. Sistem tersebut menggunakan beberapa sensor seperti sensor suhu, lux sensor, sensor kelembaban, sensor dry contact, sensor magnet-based open/close, dan sensor Passive Infrared (PIR). Data dari sensor-sensor tersebut dikirim melalui media nirkabel menuju iMonnit 
server melalui gateway yang berada di rumah, dan dapat dimonitor secara real time (Basu, 2013: 49-54). Sistem monitoring suhu dan kelembaban yang ditempatkan di beberapa node. Antar node saling berkomunikasi menggunakan nRF24L01+, data dikirimkan ke komputer dan ditampilkan menggunakan aplikasi berbasis web (Dwi, 2017: 267).

Implementasi sistem monitoring yang lain yaitu untuk memonitor keadaan cuaca dan mendeteksi potensi terjadinya banjir. Data dari sensor akan dikirim ke server Ubidots dan dapat diakses secara real time menggunakan aplikasi android. Data yang ditampilkan yaitu ketinggian level air, suhu, kelembaban, arah dan kecepatan angin, tekanan udara hingga curah hujan (Tri, 2017: 33-40). Penelitian yang bertujuan untuk mengetahui keadaan cuaca di suatu tempat dan memberikan laporan secara periodik. Data dari modul sensor soil moisture, suhu dan kelembaban (DHT11), tekanan barometrik (BMP180) dan sensor Light Dependent Resistor (LDR) dikirim secara nirkabel melalui jaringan Internet dan disimpan di cloud Thingspeak serta dapat diakses secara real time (Katyal, 2019: 238-240).

Pemantauan terhadap kondisi lingkungan dilakukan dengan menerapkan beberapa sensor sekaligus. Sensor pemantau kepadatan partikel debu (GP2Y1010AU0F), kadar Karbon Monoksida menggunakan sensor TGS 2600, sensor TGS 2201 untuk mendeteksi kadar Nitrogen Dioksida dan Hidrokarbon, sensor SHT11 pendeteksi kelembaban dan suhu, intensitas cahaya dideteksi dengan BH1750, Real Time Clock (RTC) digunakan modul DS1307, serta modul GPS GY-GPS6MV2 dijadikan sebagai penanda lokasi. Informasi dari sensor-sensor tersebut ditampilkan melalui penampil dot matrik dan dikounikasikan menggunakan modul nRF905 (Nurhuda, 2016: 353). Stasiun cuaca berbasis Internet of Things (IoT) dengan menggunakan sensor kelembaban dan suhu (DHT11), BMP180 sebagai sensor tekanan barometrik, sensor LDR dan modul raindrop. Data dari setiap sensor dikirimkan melalui ESP8266 ke cloud IBM. Notifikasi dikirimkan melalui SMS, email dan twitter post (Kodali, 2016: 680-683). Penggunaan telemetri dengan frekuensi 433 megahertz (Mhz) untuk mengirimkan data dari sensor kelembaban, suhu dan tekanan udara pada sistem pemantauan ke ground station. Data hasil pengiriman tersebut disajikan dalam bentuk antarmuka berupa grafik (Budi, 2016: 438441).

Penelitian yang lain menerangkan bahwa sensor hujan (raindrop sensor) dapat digunakan untuk mendeteksi apakah terjadi hujan atau tidak, dalam penelitianya yang membahas tentang sistem pemantauan cuaca menjelaskan bahwa, sensor hujan bekerja berdasarkan perubahan nilai hambatan pada board sensor ketika mendeteksi air yang menyebapkan arus mengalir sehingga menandakan akan terjadi hujan, semakin banyak air yang mengenai sensor, semakin cepat perubahan resistan pada sensor (Kedia, 2016: 315-322). Begitupun penelitian yang lain menjelaskan bahwa sensor hujan dapat bekerja berdasarkan prinsip kapasitif untuk mendeteksi adanya tetesan air, pada penelitianya sensor hujan digunakan sebagai pemantau parameter cuaca (Handy, 2017: 21-25).

Pada penelitian yang lain menggunakan sensor hujan dan sensor suhu (NTC Thermistor) sebagai sistem pemantau untuk mendeteksi hujan dan suhu secara real time menggunakan beberapa sensor, dalam penelitianya sistem mampu melakukan monitoring deteksi hujan dan suhu, namun pada sistem monitoring yang dikerjakan belum terdapat monitoring kelembaban serta sumber listrik masih menggunakan baterai dan adaptor (Muhamad, 2017: 20-28). Penelitian selanjutnya menerangkan bahwa sensor kelembaban (humidity) HIH-4030 mempunyai lineraritas dan kepresisian tinggi, dengan nilai kelembaban relatif aktual dalam satuan \% RH (Relative Humidity), sensor ini dapat mengukur kelembaban dari 0-100\% RH (Pocero, 2017: 54-67). 
Saat ini, sistem monitoring banyak di kembangkan dalam berbagai perangkat elektronik, namun beberapa sistem monitoring tersebut belum terintegrasi menjadi satu sistem, salah satunya adalah sistem monitoring pendeteksian hujan, suhu dan kelembaban. Pada beberapa kasus, untuk melakukan pendeteksian hujan, suhu dan kelembaban di daerah atau wilayah tertentu, petugas yang melakukan monitoring harus mendatangi lokasi atau wilayah tersebut dengan berbagai kondisi dan medan yang berubah-ubah, selain itu sinyal telekomunikasi maupun internet yang tidak terjangkau pada daerah yang ingin dilakukan pemantauan, sehingga dalam melakukan monitoring, petugas harus berada pada lokasi tersebut dalam waktu yang lama dengan kondisi sumber listrik terbatas.

Sistem monitoring pada penelitian ini melakukan pendeteksian hujan berdasarkan sensor hujan (raindrop sensor), sensor NTC Thermistor sebagai pendeteksi suhu dan sensor HIH-4030 sebagai pendeteksi kelembaban, sistem monitoring ini memiliki sumber listrik berbasis solar DC power system dan pemantauan berbasis GUI (graphical user interface) menggunakan processing yang dapat menampilkan data-data monitoring melalui komputer (PC atau Laptop) dari jarak jauh melalui sistem telemetri.

\section{METODE}

Penelitian ini terbagi atas beberapa bagian utama diantaranya, perancangan perangkat keras sistem monitoring dan perancangan perangkat lunak GUI sistem monitoring serta perancangan program pada mikrokontroller.

Blok diagram perancangan perangkat keras pada penelitian ini diperlihatkan pada Gambar 1. Terdapat dua buah bagian sistem yaitu, blok diagram untuk melakukan monitoring yang ditunjukkan pada bagian $\mathrm{A}$. Pada bagian $\mathrm{B}$ menunjukkan blok diagram bagian yang digunakan untuk mendeteksi hujan, suhu dan kelembaban.

Pada bagian $\mathrm{B}$ terdiri dari mikrokontroller Arduino Mega 2560 dengan tiga buah sensor, diantaranya sensor hujan (raindrop sensor), sensor suhu (NTC Thermistor) dan sensor kelembaban (HIH4030), ketiga sensor tersebut memilki keluaran (output) berupa tegangan atau analog, ketiga keluaran sensor yang digunakan diinputkan pada Arduino Mega 2560 sebagai mikrokontroller pemrosesan data pembacaan sensor dengan pembagian Pin inputan sebagai berikut, A0 (analog 0) sebagai inputan sensor suhu, A1 (analog 1) sebagai inputan sensor hujan, A2 (analog 2) sebagai inputan sensor kelembaban, ketiga inputan sensor tersebut kemudian di konversi menjadi data digital melalui fasilitas ADC (analog digital converter) Arduino Mega 2560 untuk kemudian dapat di olah sebagai data-data informasi monitoring pendeteksian hujan, suhu dan kelembaban.

Untuk melengkapi data pewaktuan hasil monitoring digunakan sebuah Real time clock (RTC) yang dihubungkan pada Pin 20 (SDA) dan Pin 21 (SCL) Arduino Mega 2560 sebagai komunikasi I2C (Inter-Integrated Circuit), sedangkan radio telemetri yang dihubungkan pada Pin TX0 dan RX0 Arduino Mega 2560 digunakan agar data-data hasil monitoring dapat di transmisikan (TX) secara nirkabel. Pada bagian catu daya sistem monitoring ini menggunakan PLTS (pembangkit listrik tenaga surya) berbasis solar DC power system, sehingga sistem monitoring ini tidak bergantung pada sumber listrik lain.

Pada bagian A atau penerima ( $\mathrm{RX}$ ), radio telemetri menerima data-data monitoring pendeteksian hujan, suhu dan kelembaban dari radio telemtri (TX), data-data hasil monitoring kemudian dapat di akses melalui PC atau Laptop berdasarkan antarmuka GUI berbasis processing. 


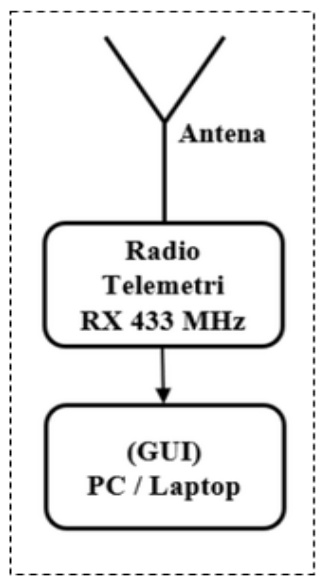

A

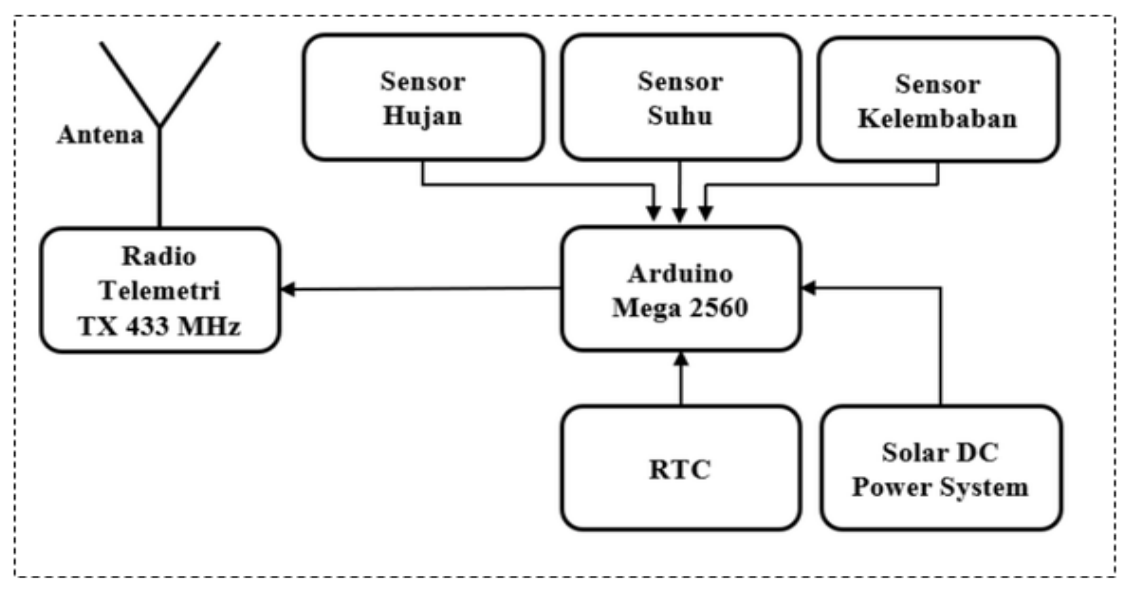

B

Gambar 1. Blok Diagram Perancangan Perangkat Keras

Sistem pemantauan mempunyai beberapa komponen perangkat keras, baik itu perangkat utama maupun komponen-komponen elektronika. Komponen yang pertama yaitu sensor raindrop. Sensor ini mempunyai kemampuan dalam mendeteksi hujan maupun kondisi hujan yang terjadi di sekitarnya, sensor ini mampu berfungsi sebagai switch, saat terjadi tetesan air hujan yang jatuh melalui raining board yang terdapat pada sensor, selain itu sensor mampu mengukur intensitas curah hujan. Keluaran analog dari sensor raindrop berfungsi sebagai pendeteksi hujan, dengan kondisi nilai keluaran sensor tinggi mengindikasikan saat tidak mendeteksi hujan, sedangkan pada saat sensor mendeteksi hujan, nilai keluaran sensor bernilai rendah (Katyal, 2019), (Muhamad, 2017).

Thermistor adalah resistor yang peka terhadap perubahan temperatur, pada umumnya ada dua tipe dasar thermistor yaitu Negative Temperature Coefficient (NTC) dan Positive Temperature Coefficient (PTC). Untuk tipe thermistor NTC paling cocok digunakan pada pengukuran temperatur yang presisi, sedangkan untuk tipe PTC paling cocok digunakan sebagai aplikasi saklar elektronik yang peka terhadap perubahan temperatur. Pada penelitian ini thermistor yang digunakan sebagai pengukur temperatur adalah thermistor NTC $10 \mathrm{k} \Omega$, untuk dapat mengukur temperatur thermistor, digunakan metode rangkaian pembagi tegangan seperti diperlihatkan pada Gambar 2 (Arief, 2016: 103-108).

Komponen berikutnya yaitu radio telemetri. Radio telemetri yang digunakan adalah modul RCTimer Radio Telemetry Kit 433Mhz. Radio telemetri ini bersifat open source telemetri sebagai salah satu opsi selain Xbee. Telemetry ini mempunyai kemampuan berkomunikasi secara jarak jauh kurang lebih sekitar satu mil. Sistem telemetri ini menggunakan komunikasi full-duplex berbasis modul HopeRF HM-TRP. Interface dapat menggunakan USB FTDI maupun TTL serial standar 5 Volt. AT Command atau 3DR Radio Configurator dapat digunakan untuk melakukan konfigurasi pada telemetri jenis ini, sedangkan untuk mengatur dan memperbarui modul ini dapat digunakan APM Mission Planner (Muhamad, 2017).

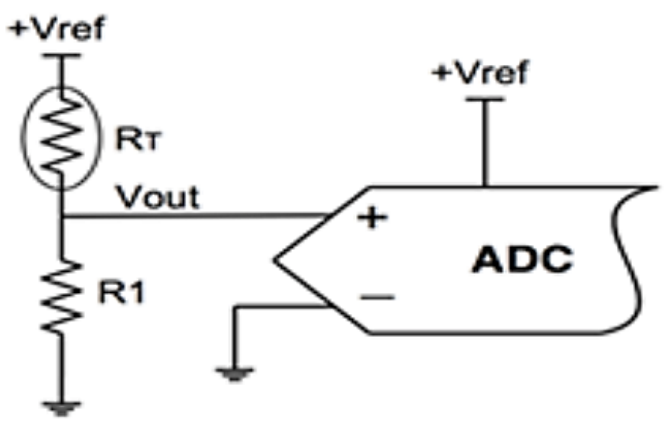

Gambar 2. Grafik Skenario Nilai ADC Sensor Hujan 
Pembangkit listrik yang mempunyai sumber energi yang bersumber pada energi matahari disebut sebagai Pembangkit Listrik Tenaga Surya (PLTS). Sumber yang berasal dari energi matahari kemudian diubah menjadi energi listrik berdasarkan teknologi photovoltaic. Photovoltaic adalah sebuah piranti semikonduktor yang dapat mengubah cahaya secara lansung menjadikan arus listrik searah (DC) berdasarkan kristal silicon yang tipis. PLTS yang digunakan pada penelitian ini berbasis solar DC power system yang telah dilengkapi modul baterai. Berikut spesifikasi solar DC power system yang digunakan pada penelitian ini :

$\begin{array}{ll}\text { Solar Panel Power } & : 4 \text { Watt } \\ \text { Optimum Operating Voltage } & : 10.75 \text { Volt } \\ \text { Internal Battery Type } & : \text { Lithium } \\ \text { Battery voltage } & : 7.4 \text { Volt } \\ \text { Battery Capacity } & : 4000 \mathrm{mAh}\end{array}$

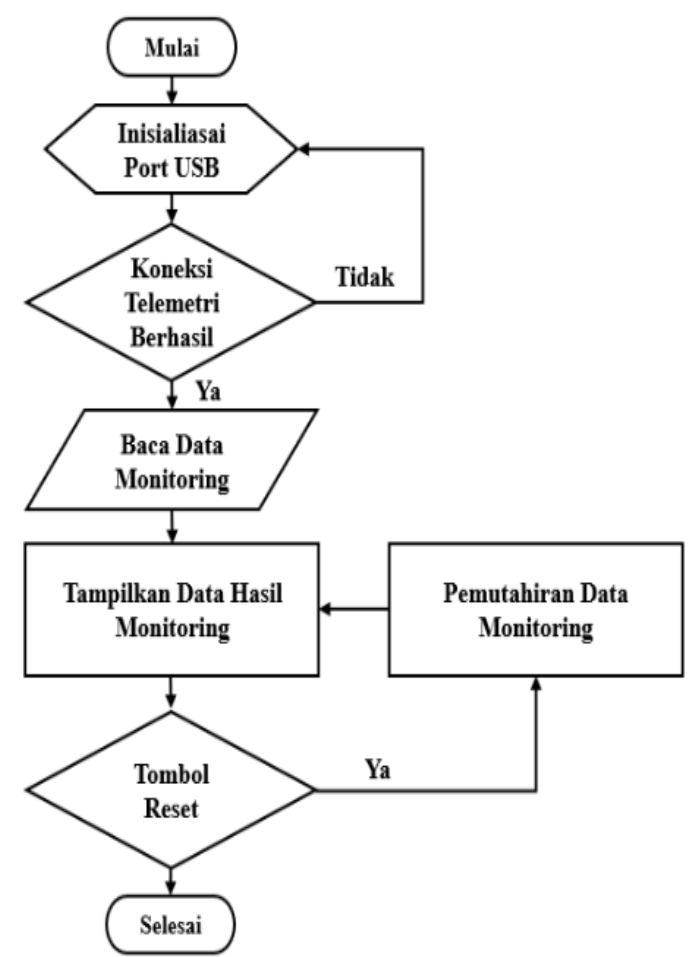

Gambar 3. Diagram Alir Perancangan Perangkat Lunak Sisi Penerima

Sensor yang digunakan sebagai pendeteksi kelembaban pada penelitian ini adalah HIH-4030, sensor ini mempunyai lineraritas dan kepresisian tinggi, dengan nilai kelembaban relatif aktual dalam satuan \%RH, sensor ini dapat mengukur kelembaban dari 0 $-100 \%$ RH. Sensor ini memiliki output berupa tegangan (analog) 0,958 -4,53V, dengan sumber tegangan sebesar tegangan sebesar 5 Volt (Pocero, 2017: 54-67). Dalam penggunaanya, sensor kelembaban HIH-4030 dapat langsung digunakan dengan mikrokontroller Arduino menggunakan SparkFun HIH-4030 Arduino Library (Github, 2016).

Real time clock (RTC) yang digunakan pada penelitian ini adalah tipe RTC DS1307. RTC jenis ini merupakan salah satu sensor yang dapat menyimpan variable waktu, tanggal, dan tahun secara real time. Komunikasi yang digunakankan oleh sensor DS1307 adalah komunikasi $12 \mathrm{C}$ yang hanya membutuhkan 2 buah port SDA dan SCL untuk membaca isi register dari sensor RTC. Untuk mengaktifkan RTC DS1307 dibutuhkan tengangan input sebesar $3 \mathrm{~V}$ yang diperoleh dari baterai CMOS agar dapat menyimpan data waktu, sehingga apabila suplai 3V tersebut terputus maka settingan waktu pada RTC akan kembali pada konfigurasi awal (Muhamad, 2017).

Penelitian ini menggunakan mikrokontroller berjenis Arduino dengan tipe Arduino Mega 2560. Arduino merupakan sebuah platform Electronic open source, berbasis pada perangkat lunak dan keras yang bersifat fleksibel dan mudah digunakan, yang ditunjukkan untuk para desainer, seniman, dan semua orang yang berminat dalam membuat suatu objek atau lingkungan yang interaktif. Nama Arduino juga tidak hanya dipakai untuk menamai board rangkaiannya saja, tetapi juga untuk menamai bahasa dan perangkat lunak pemrogramannya (Dian, 2012).

Terdapat dua bagian perancangan perangkat lunak pada sistem ini yaitu, perangkat lunak yang berada di sistem monitoring dan perangkat lunak yang nantinya digunakan untuk menampilkan data dari sistem monitoring. Perangkat lunak ini yang akan 
diinstal di laptop. Diagram alir perancangan perangkat lunak pada sistem monitoring dapat dilihat pada Gambar 3. Proses pengiriman data dari sisi pendeteksian diawali dengan pembacaan data dari sensor, kemudian akan diproses oleh Arduino Mega 2560. Nilai dari sensor berupa sinyal masukan analog, sehingga perlu diubah menjadi sinyal digital menggunakan ADC. Data tersebut akan diterima oleh Arduino dan disimpan. Data tersebut meliputi informasi tanggal dan waktu, kondisi cuaca, suhu dan kelembaban. Beberapa parameter tersebut kemudian dikirim melalui transmisi data menggunakan modul radio telemetri $433 \mathrm{MHz}$. Diagram alir perancangan perangkat lunak sisi penerima atau nantinya yang akan diinstal di laptop dapat dilihat pada Gambar 4. Perangkat lunak sebagai antarmuka untuk menampilkan data dari sensor tersebut diprogram menggunakan bahasa pemrograman processing.

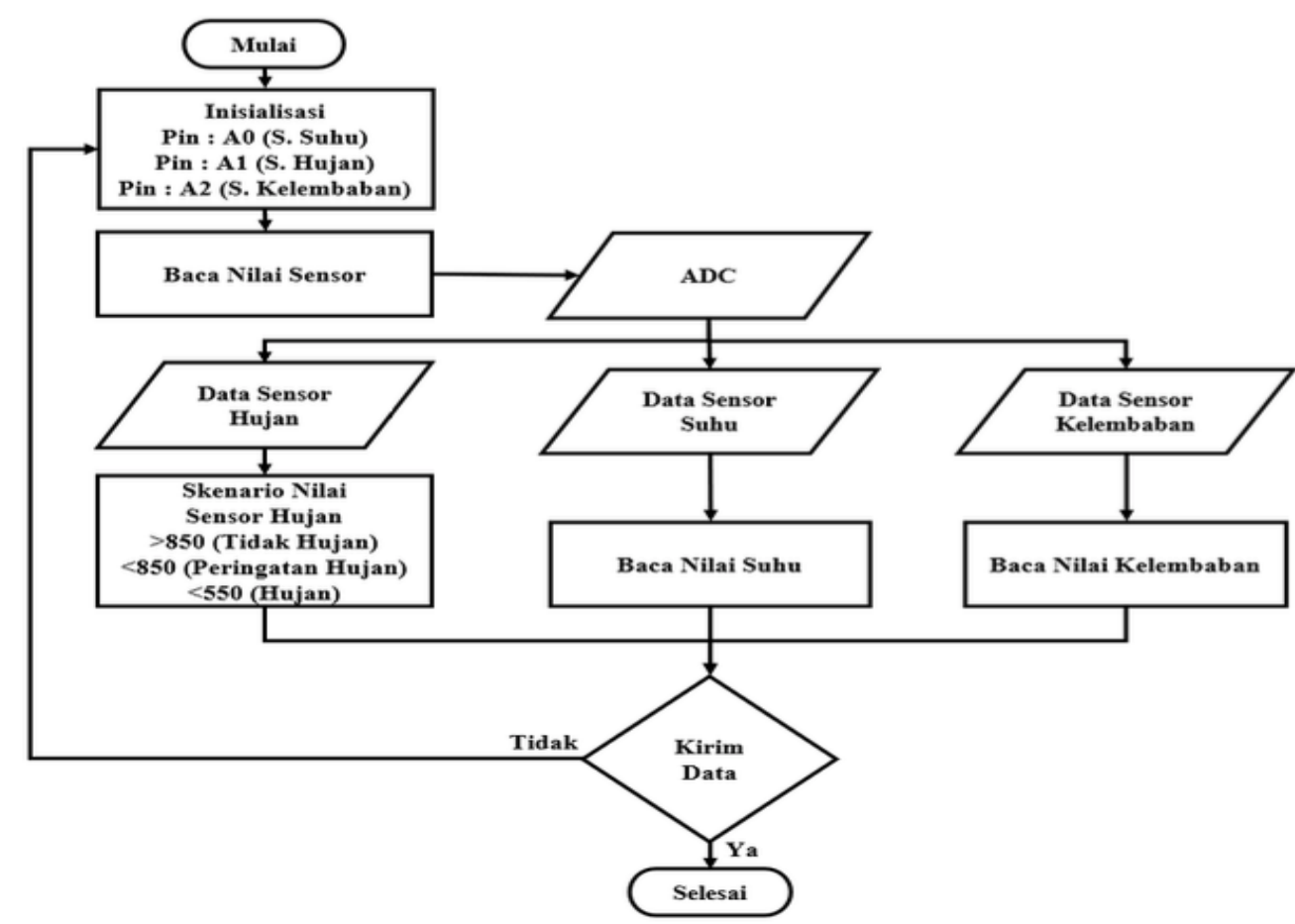

Gambar 4. Diagram Alir Perancangan Perangkat Lunak Pada Sisi Sistem Monitoring

\section{HASIL DAN PEMBAHASAN}

Pada penelitian ini, pengujian sensor terbagi dalam tiga bagian, diantaranya pengujian sensor hujan yang digunakan untuk mendeteksi keadaan cuaca hujan atau tidak hujan, pengujian sensor suhu yang digunakan untuk mendeteksi suhu dan pengujian sensor kelembaban yang digunakan untuk mendeteksi nilai kelembaban.

Pada hasil pengujian sensor hujan (raindrop sensor), didapatkan nilai desimal ADC (analog digital converter) minimum
(Min) dan maksimum (Max), seperti yang terlihat pada Tabel 1.

Tabel 1. Nilai ADC Minimum dan Maksimum Sensor Hujan

\begin{tabular}{cc}
\hline $\begin{array}{c}\text { Nilai Decimal ADC } \\
\text { Minimum }\end{array}$ & $\begin{array}{c}\text { Nilai Decimal ADC } \\
\text { Maksimum }\end{array}$ \\
\hline 250 & 1023 \\
\hline
\end{tabular}

Seperti yang terlihat pada Tabel 1 , nilai minimum ADC sensor hujan adalah 250, sedangkan nilai maksimum ADC sensor hujan adalah 1023, kondisi tersebut diperoleh pada saat dilakukan pengujian sensor hujan, yaitu 
pada saat bagian sensor sepenuhnya terkena air (diskenariokan hujan) diperoleh nilai minimum ADC, sedangkan pada saat bagian sensor hujan tidak terkena air (diskenariokan tidak hujan) diperoleh nilai maksimum ADC. Dari kondisi nilai ADC tersebut, pada penelitian ini dibuat skenario nilai ADC sensor hujan yang dijadikan acuan pada sistem monitoring pendeteksian hujan, skenario nilai ADC sensor hujan diperlihatkan pada Gambar 5. Dapat dilihat bahwa, nilai ADC sensor hujan dibagi dalam tiga skenario keadaan berdasarkan nilai masingmasing ADC, diantaranya kondisi tidak hujan (bagian sensor tidak mendeteksi air), kondisi peringatan hujan dengan nilai ADC $<850$ (sebagian sensor terkena air), serta kondisi hujan dengan nilai ADC $<550$ (bagian seluruh sensor terkena air), tiga kondisi inilah yang dijadikan acuan sistem pendeteksian hujan pada penelitian ini.

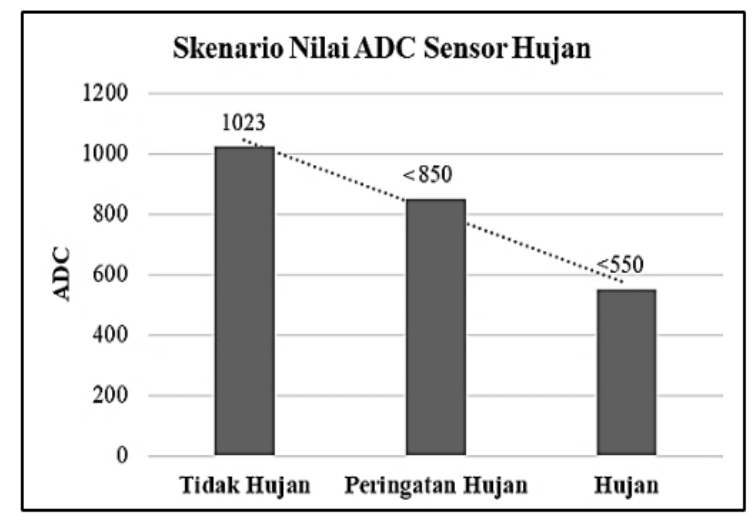

Gambar 5. Grafik Skenario Nilai ADC Sensor Hujan

Pada pengujian sensor suhu thermistor NTC $10 \mathrm{k} \Omega$, digunakan sebuah alat ukur tambahan (TES 1365 Datalogging Humidity Temperature Meter) sebagai pembanding untuk mengetahui kehandalan sistem yang telah di buat. Hasil pengujian sensor suhu diperlihatkan pada Tabel 2.

Pengujian dilakukan sebanyak 12 kali percobaan secara random diluar ruangan, dari hasil pengujian didapatkan nilai selisih antara pembacaan suhu thermistor NTC $10 \mathrm{k} \Omega$ dan pembacaan suhu TES 1365 Datalogging, untuk mengetahui nilai rata-rata selisih pembacaan suhu digunakan perhitungan seperti ditunjukkan pada persamaan 1 .

$$
\text { Rerata selisih pembacaan suhu }=\frac{\text { Jumlah selisih }}{\text { Jumlah Pengujian }}
$$

Dapat dilihat dari hasil perhitungan pada persamaan 2, selisih antara pembacaan suhu Thermistor NTC $10 \mathrm{k} \Omega$ dan pembacaan suhu TES 1365 Datalogging kecil, dengan nilai ratarata selisih $0,4^{0} \mathrm{C}$.

$$
\text { Rerata selisih pembacaan suhu }=\frac{5,5}{12}=0,4^{\circ} \mathrm{C}
$$

Sama halnya dengan pengujian sensor suhu, pada pengujian sensor kelembaban HIH4030 digunakan sebuah alat ukur tambahan (TES 1365 Datalogging Humidity Temperature Meter) sebagai pembanding untuk mengetahui kehandalan sistem yang telah di buat. Hasil pengujian sensor kelembaban diperlihatkan pada Tabel 3.

Dapat dilihat pada Tabel 3, jumlah pengujian sebanyak 12 kali percobaan yang dilakukan secara random diluar ruangan. Dari hasil pengujian sensor kelembaban didapatkan nilai selisih antara pembacaan sensor kelembaban HIH-4030 dan pembacaan kelembaban TES 1365 Datalogging, sehingga untuk mengetahui nilai rata-rata selisih pembacaan kelembaban digunakan perhitungan menggunakan persamaan 3 .

Rerata selisih pembacaan kelembaban $=\frac{\text { Jumlah selisih }}{\text { Jumlah Pengujian }}$

Dari hasil perhitungan selisih antara pembacaan sensor kelembaban HIH-4030 dan pembacaan alat ukur kelembaban TES 1365 Datalogging kecil, dengan nilai rata-rata selisih sebesar 0,7\% Relative Humidity (RH), seperti diperlihatkan pada persamaan 4 .

$$
\text { Rerata selisih pembacaan kelembaban }=\frac{8,6}{12}=0,7 \% \mathrm{RH}
$$


Hasil perancangan GUI menggunakan processing diperlihatkan pada Gambar 6 . Dengan menggunakan Processing dapat menghasilkan sebuah model antarmuka berbasis GUI yang dapat digunakan sebagai perangkat lunak monitoring pendeteksian hujan, suhu dan kelembaban secara interaktif.

Tabel 2. Hasil Pengujian Sensor Suhu

\begin{tabular}{cccc}
\hline Percobaan & $\begin{array}{c}\text { Pembacaan Suhu Termistor } \\
\text { NTC 10 k } \Omega \\
\text { (derajat) }\end{array}$ & $\begin{array}{c}\text { Pembacaan Suhu TES 1365 } \\
\text { Datalogging } \\
\text { (derajat) }\end{array}$ & $\begin{array}{c}\text { Selisih } \\
\text { (derajat) }\end{array}$ \\
\hline 1 & 29,4 & 29,5 & 0,1 \\
2 & 29,5 & 29,3 & 0,2 \\
3 & 29,5 & 29,4 & 0,1 \\
4 & 29,5 & 29,4 & 0,1 \\
5 & 29,6 & 29,5 & 0,1 \\
6 & 29,5 & 29,0 & 0,5 \\
7 & 29,6 & 29,4 & 0,2 \\
8 & 29,6 & 29,0 & 0,6 \\
9 & 29,8 & 29,3 & 0,5 \\
10 & 30,5 & 29,4 & 1,1 \\
11 & 30,8 & 29,4 & 1,4 \\
12 & 29,9 & 29,3 & 0,6 \\
\hline
\end{tabular}

Tabel 3. Hasil Pengujian Sensor Kelembaban

\begin{tabular}{cccc}
\hline Percobaan & $\begin{array}{c}\text { Pembacaan Kelembaban } \\
\text { HIH-4030 } \\
\text { (derajat) }\end{array}$ & $\begin{array}{c}\text { Pembacaan Kelembaban TES } \\
\text { 1365 Datalogging (derajat) }\end{array}$ & $\begin{array}{c}\text { Selisih } \\
\text { (derajat) }\end{array}$ \\
\hline 1 & 60,1 & 58,6 & 1,5 \\
2 & 59,9 & 58,9 & 1,0 \\
3 & 59,1 & 58,8 & 0,3 \\
4 & 58,5 & 58,0 & 0,5 \\
5 & 59,0 & 59,1 & 0,1 \\
6 & 58,2 & 58,9 & 0,7 \\
7 & 58,4 & 59,1 & 0,7 \\
8 & 57,7 & 58,8 & 1,1 \\
9 & 57,4 & 58,6 & 1,2 \\
10 & 58,5 & 59,2 & 0,7 \\
11 & 58,9 & 59,2 & 0,3 \\
12 & 58,2 & 58,7 & 0,5 \\
\hline
\end{tabular}

Hasil rancang bangun GUI (graphical user interface) sistem monitoring nirkabel pendeteksian hujan, suhu dan kelembaban berbasis Processing dapat dilihat pada Gambar 6. Seperti yang terlihat pada Gambar 7, hasil monitoring pendeteksian hujan, suhu dan kelembaban dapat di pantau secara interaktif melalu antarmuka GUI (graphical user interface) berbasis processing secara nirkabel. Sistem monitoring ini mampu menyajikan hasil pembacaan sensor secara real time dan dikirimkan setiap 30 detik, sehingga sistem monitoring ini dapat di implementasikan secara riil. Gambar 8 memperlihatkan hasil-hasil pengujian sistem monitoring pendeteksian hujan, suhu dan kelembaban. 


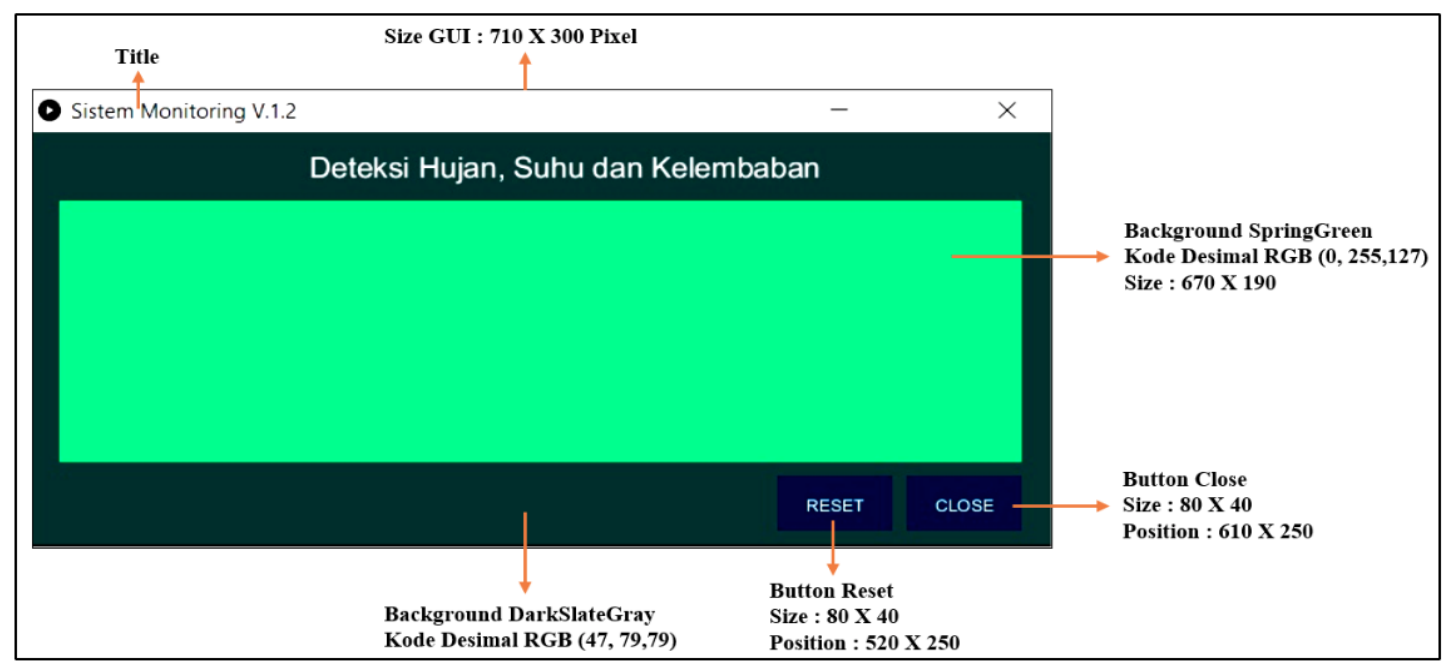

Gambar 6. Hasil Perancangan GUI

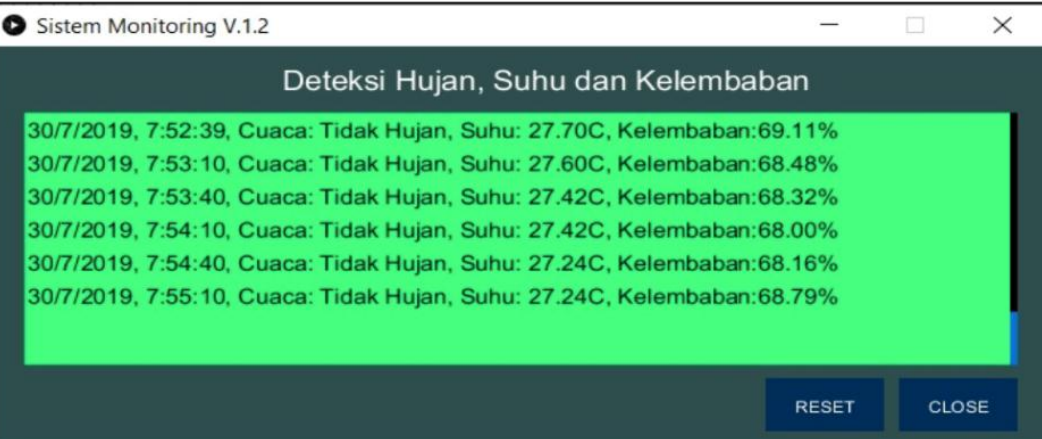

Gambar 7. GUI Sistem Monitoring Nirkabel Pendeteksian Hujan, Suhu dan Kelembaban

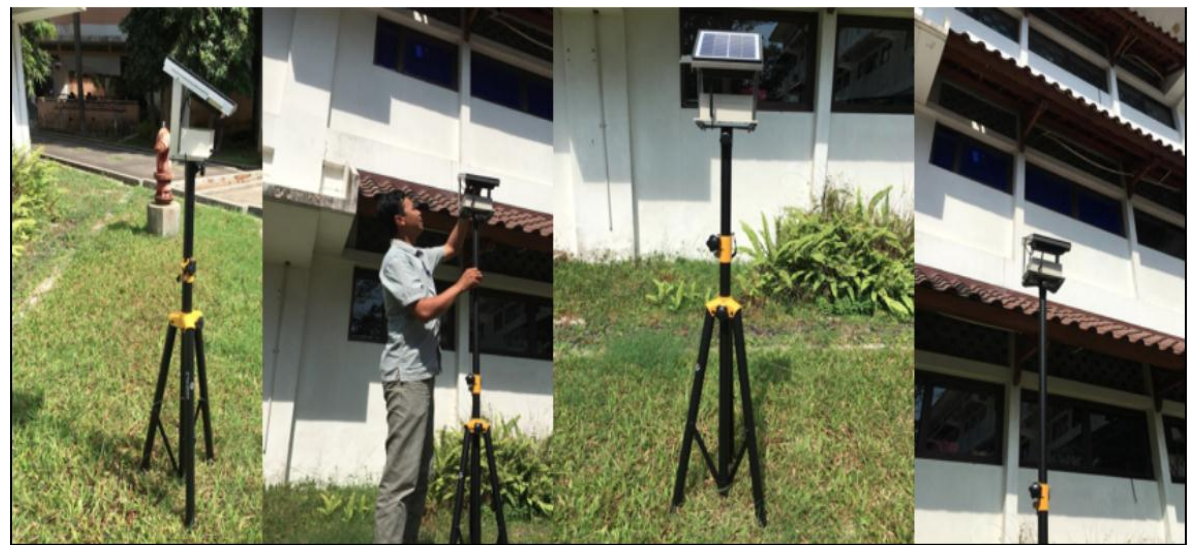

Gambar 8. Pengujian Sistem Monitoring Pendeteksian Hujan, Suhu dan Kelembaban

\section{SIMPULAN}

Berdasarkan hasil percobaan dan analisa yang telah dilakukan, sistem monitoring yang telah di implementasikan pada penelitian ini dapat melakukan fungsi monitoring pendeteksian hujan, suhu dan kelembaban secara real time melalui komunikasi nirkabel. Hasil perancangan GUI berdasarkan processing mampu menghasilkan sebuah perangkat lunak monitoring yang dapat menampilkan antarmuka pendeteksian hujan, suhu dan kelembaban melalui PC atau Laptop. Sensor raindrop memiliki sensitivitas baik dalam mendeteksi air, dibuktikan dengan rentang nilai ADC 250 ( $\min )$ - $1023(\max )$, sehingga dapat dimodelkan dalam beberapa skenario pendeteksian hujan. Penggunaan sensor suhu Thermistor NTC 10 $\mathrm{k} \Omega$ dan sensor kelembaban HIH-4030 memiliki 
nilai pembacaan yang baik. Hal ini dibuktikan dari perbandingan rata-rata selisih pembacaan menggunakan alat ukur dan sensor, 0,40C untuk selisih pembacaan suhu dan $0,7 \% \mathrm{RH}$ untuk selisih pembacaan kelembaban.

Pengembangan pada sistem monitoring pendeteksian hujan, suhu dan kelembaban dapat di tingkatkan lagi, sehingga tidak hanya dapat mendeteksi satu lokasi monitoring melainkan dapat melakukan monitoring lebih dari satu lokasi tertentu melalu sistem berbasis WSN (wireless sensor network), sehingga sistem monitoring dapat diakses tidak hanya melalui PC atau Laptop melainkan melalui gawai dan Tablet. Selain itu dalam pengembangannya dapat ditambahkan Global Positioning System (GPS) pada sistem monitoring ini, sehingga dapat diketahui lokasi dimana sistem ditempatkan. Pengembangan yang lain dengan menambahkan sistem monitoring kapasitas baterai sehingga informasi dapat diakses dan kehilangan daya listrik dapat diminimalisir.

\section{DAFTAR RUJUKAN}

Arief Budijanto \& Achmad Shoim. 2016. Pembelajaran Embedded System Berbasis Proyek Menggunakan Arduino Mega 2560. Prosiding SNST ke-7, di Jurusan Teknik Elektro 2016. No. 2011: 103-108.

Basu Debraj, Moretti Giovanni, Gupta Sen Gaurab, and Marsland Stephen. 2013. Wireless sensor network based smart home: Sensor selection, deployment and monitoring. Texas: 8th IEEE Sensors Applications Symposium (SAS) 2013.

Budi Setiyono, Sumardi, \& Rafdito Harisuryo. 2016. Measurement system of temperature, humidity and air pressure over $433 \mathrm{MHz}$ radio frequency: An application on quadrotor. ICITACEE 2015 - 2nd Int. Conf. Inf. Technol. Comput. Electr. Eng. Green Technol. Strength. Inf. Technol. Electr. Comput. Eng. Implementation, Proc: 438-441.

Dian Artanto. 2012. Interaksi Arduino dan
LabVIEW. Jakarta: Elex Media Komputindo.

Dwi Intan Af'idah, Adian Fatchur Rochim, \& Eko Didik Widianto. 2017. Perancangan Jaringan Sensor Nirkabel (JSN) untuk Memantau Suhu dan Kelembaban Menggunakan nRF24L01+. Jurnal Teknologi dan Sistem Komputer Universitas Diponegoro. Vol. 2, No. 4: 267.

GitHub SparkFun_HIH4030_Arduino_Library: Arduino library for SparkFun's Humidity Sensor Breakout - HIH-4030. [Online]. $2016 . \quad$ Available: https://github.com/sparkfun/SparkFun_ HIH4030_Arduino_Library. [Accessed: 05-Aug-2019].

Handy Indra Regain Moseya. 2017. Pengembangan Purwarupa Node Multi Sensor Pemantau Parameter Cuaca Berbasis Mikrokontroler. Jurnal MIPA Unsrat Online. Vol. 6, No. 1: 21-25.

Katyal Amber, Yadav Ravi, \& Pandey Manoj. 2019. Wireless Arduino Based Weather Station. International Journal of Advanced Research in Computer and Communication Engineering. Vol. 5, No. 4: 238-240.

Kedia Parijit. 2016. Localised Weather Monitoring System. International Journal of Engineering Research and General Science. Vol. 4, No. 2: 315-322.

Kodali Kishore Ravi \& Mandal Snehashish. 2016. IoT based weather station. Int. Conf. Control Instrum. Commun. Comput. Technol. ICCICCT 2016: 680683.

Muhamad Yusvin Mustar \& Rama Okta Wiyagi. 2017. Implementasi Sistem Monitoring Deteksi Hujan dan Suhu Berbasis Sensor Secara Real Time (Implementation of Rain Detection and Temperature Monitoring System Based on Real Time Sensor). Jurnal Semesta Teknika. Vol. 20, No. 1: 20-28.

Nurhuda Maulana, Oky Dwi Nurhayati, \& Eko Didik Widianto. 2016. Perancangan Sistem Sensor Pemonitor Lingkungan 
Berbasis Jaringan Sensor Nirkabel. Jurnal Teknologi dan Sistem Komputer Universitas Diponegoro. Vol. 4, No. 2: 353.

Pocero Lidia, Amaxilatis Dimitrios, Mylonas Georgios, \& Chatzigiannakis Ioannis. 2017. Open source IoT meter devices for smart and energy-efficient school buildings. HardwareX. Vol. 1, No. March: 54-67.

Tri Rahajoeningoem \& Ivan Heru Saputra. 2017. Sistem Monitoring Cuaca dan Deteksi Banjir pada Android Berbasis Internet of Things (IoT). Prosiding Saintiks FTIK UNIKOM: 33-40. 